\title{
STUDY OF THE STRUCTURE OF PRODUCTS OF INTERACTION BETWEEN SOME NAPHTHOQUINONE DERIVATIVES AND PHARMACEUTICAL SUBSTANCES
}

\author{
BAZI NAFTOKINON TÜREVLERİ ILE ILAÇ MADDELERİ ARASINDAKİ ETKILLEŞIM \\ ÜRÜNLERININ YAPISININ INCELENMESI
}

\section{Anastasiia DONCHENKO ${ }^{1, *}$ (D) , Katerina MIEDVIEDIEVA ${ }^{1}$ (D), Oleksii VOSKOBOINIK $^{2}$ (D), Svitlana VASYUK ${ }^{1} \mathbb{D}^{\mathbb{D}}$, Serhii KOVALENKO ${ }^{2}$}

${ }^{1}$ Zaporizhzhia State Medical University, Faculty of Pharmacy, Department of Analytical Chemistry, 69035, Zaporizhzhia, Ukraine

${ }^{2}$ Zaporizhzhia State Medical University, Faculty of Pharmacy, Department of Organic and Bioorganic Chemistry, 69035, Zaporizhzhia, Ukraine

\begin{abstract}
Objective: The purpose of the present work is to detail a study of the interaction between naphthoquinonebased analytical reagents and such pharmacologically active ingredients as acetylcysteine, $\beta$-alanine and taurine (2-aminoethanesulfonic acid) including the isolation and structure elucidation of the formed products.

Material and Method: UV-visible spectrophotometry was applied to determine the stoichiometric coefficients of reactants in reactions between the pharmaceutical substances and naphthoquinone derivatives. $1 H$ NMR-spectroscopy, IR spectroscopy, chromatomass-spectrometry were used to prove the structure of the reaction products.

Result and Discussion: The stoichiometric relationships of the reactants in the investigated medicinal substances reactions with quinone derivatives were determined by the methods of saturation and continuous changes. They are 1:1 in each case. According to the determined relationships of components reaction and optimal conditions for reactions path, the products of interaction of acetylcysteine with 2,3-dichloro-1,4naphthoquinone and taurine, $\beta$-alanine with sodium 1,2-naphthoquinone-4-sulfonate were isolated and identified. In order to establish the structure of the compounds, the 1H NMR-spectroscopy, IR spectroscopy, chromatomass-spectrometry were used.
\end{abstract}

Keywords: Acetylcysteine, $\beta$-alanine, taurine, naphthoquinone derivatives, reaction products

\footnotetext{
* Corresponding Author/Sorumlu Yazar: Anastasiia Donchenko e-mail / e-posta: donchenko130791 @ gmail.com, Phone / Tel.: +380978520282
} 


\section{ÖZ}

Amaç: Naftokinon esasl analitik reaktiflerin asetilsistein, $\beta$-alanin ve taurin (2-aminoetanosülfonik asit) gibi farmasötik açıdan aktif maddelerle etkilişimin, oluşan ürünlerin ayırımı yapı oluşumu dahil olmak üzere detayl incelemesidir.

Gereç ve Yöntem: Farmasötik maddeler ile naftokinon türevleri arasındaki reaksiyonlarda reaktanların stokiyometrik katsayılarını belirlemek için UV - Vis spektrofotometri yöntemi uygulandı. Reaksiyon ürünlerinin yapısını kanıtlamak için 1H NMR-spektroskopi, IR spektroskopi, kütle spektrometrisi kullanıldi.

Sonuç ve Tartışma: Kinon türevleri ile araştırılan tıbbi maddelerin reaksiyonlarında reaktanların stokiyometrik ilişkileri, doyurma ve sürekli değişim yöntemleri ile belirlenmiştir. İlişki her durumda 1: 1'dir. Bileşen reaksiyonu ve reaksiyon yolu için optimal koşulların belirlenen ilişkilerine göre, asetilsisteinin 2,3dikloro-1,4-naftokinon ve taurin ile, $\beta$-alanin ile sodyum 1,2-naftokinon-4-sülfonat ile etkileşim ürünleri izole edilmiş ve tanımlanmıştır. Bileşiklerin yapısını oluşturmak için 1 H NMR-spektroskopi, IR spektroskopisi, kütle spektrometrisi kullanılmıştır.

Anahtar Kelimeler: Asetilsistein, $\beta$-alanin, taurin, naftokinon türevleri, reaksiyon ürünleri

\section{INTRODUCTION}

Naphthoquinones are known as high reactive compounds, that intensively studied as promising bioactive agents [1, 2], mediators in oxidation processes [3] and dyes [4]. Lately, the abovementioned compounds repeatedly described as reagents used for the colorimetric quantitative determination of various pharmacologically active ingredients and biologically significant compounds. Among substituted naphthoquinones dichlone (2,3-dichloro-1,4-naphthoquinone) and 1,2-naphthoquinone-4sulphonic acid sodium salt proved to be the most widely used colorizing reagents. Thus, dichlone was proposed as an effective reagent for quantitative determination of primary amines [5]. The spectrophotometric estimation of piperazine in dosage forms using dichlone and acetaldehyde as reagents was described as one of the possible modifications of elaborated before analytical methods [6]. Charge-transfer reaction of 2,3-dichloro-1,4-naphthoquinone with crizotinib was used for development of microwell assay for its quantitative determination in capsules [7]. Authors substantiated the nature of the abovementioned reaction products by computation approaches [8]. Also, 2,3-dichloro-1,4naphthoquinone found to be an effective colorizing reagent for spectrophotometric determination of isoniazid in presence of its hydrazones.

Data related to the application of 1,2-naphthoquinone-4-sulphonic acid sodium salt for the spectrophotometric quantitative determination of amino-group containing pharmaceuticals in various objects were generalized and critically evaluated in the comprehensive review by Elbashir A.A. et al [9]. It was shown that usage of 1,2-naphthoquinone-4-sulphonic acid sodium salt was reasonable for quantitative determination of analytes as in dosage forms so in biological material (urine and plasma). The authors also summarized the information about optimal conditions of derivatization processes.

After publication of the abovementioned review 1,2-naphthoquinone-4-sulphonic acid sodium salt was described as valued colorizing reagents for spectrophotometric determination of cefotaxime [10] and other cephalosporins [11], finasteride [12], folic acid [13], rimantadine and memantine [14] 
etc. 1,2-Naphthoquinone-4-sulphonate reagent also may be used for continuous-flow spectrophotometric determination of amino acids [15]. Some methods of pharmacologically active ingredients quantification require the usage of 1,2-naphthoquinone-4-sulphonic acid sodium salt together with the auxiliary reagent. Thus, application of tetradecylbenzyldimethylammonium chloride for sensitivity improvement of spectrophotometric determination of dopamine hydrochloride using sodium 1,2-naphthoquinone-4-sulfonate as chromogenic reagent was studied [16]. The method of isoniazid spectrophotometric quantification using combination of 1,2-naphthoquinone-4-sulphonic acid sodium salt and cetyltrimethyl ammonium bromide as colorizing reagents was elaborated as well [17]. It should be, noted that despite the wide usage of naphthoquinone derivatives as colorizing reagents the nature of products formed by the interaction of abovementioned compounds and analytes is a controversial issue. Some of the authors made assumptions about structure of the products of interactions between naphthoquinone colorizing reagents and analytes. As usual, their suppositions were based on data about stoichiometric coefficients of reactants, described chemical modification of naphthoquinone derivatives [4, 18] and computation approaches [19]. However, structures of the major and minor products formed in conditions of quantitative determination were not evaluated using appropriate physicochemical methods. Obviously understanding of the nature of processes that take place during the analytical reaction and structure of the products are essential for the improving of quantifying methods.

The present work was aimed at the detailed study of interaction between naphthoquinone-based analytical reagents and such pharmacologically active ingredients as acetylcysteine, $\beta$-alanine and taurine (2-aminoethanesulfonic acid) $[20,21]$ including the isolation and structure elucidation of the formed products.

\section{MATERIAL AND METHOD}

\section{Reagents and chemicals}

Analytical grade chemicals: 2,3-Dichloro-1,4-napthoquinone, sodium 1,2-naphthoquinone-4sulfonate, sodium hydroxide, DMF, 2-propanol, 1,4-dioxane, ethanol and HPLC grade solvents: acetonitrile and water were obtained from commercial sources. The reference standards of acetylcysteine, taurine and $\beta$-alanine at $99,9 \%$ purity were provided by the chemical pharmaceutical enterprises (Ukraine).

\section{Instrumentation}

Analytic Jena UV-visible spectrophotometer model Specord 200 with $1 \mathrm{~cm}$ matched quartz cells were used for UV-Vis studies. Kern electronic scales ABT-120-5DM was used measuring of the weight. Water bath Memmert WNB 7-45 was used for heating of reaction mixtures. 
IR spectra (4000-600 $\mathrm{cm}-1)$ were recorded on a Bruker ALPHA FT-IR spectrometer using a module ATR eco ZnSe. 1H NMR spectra (400 MHz) were recorded on a Varian-Mercury 400 (Varian Inc., Palo Alto, CA, USA) spectrometers with TMS as internal standard in DMSO-d6 solution.

Mass spectra were recorded on a high performance liquid chromatograph «Agilent 1100 Series» (Agilent, Palo Alto, CA, USA) equipped with DAD, ELSD and MSD «Agilent LC/MSD SL».

\section{Chromatographic conditions}

Column «Zorbax SB-C18»-1.8 $\mu \mathrm{m}, 4.6 \mathrm{~mm}$ x $15 \mathrm{~mm}$. Eluent: A - CH3CN-H2O (95:5), $0.1 \% \mathrm{HCOOH}, \mathrm{B}-\mathrm{H} 2 \mathrm{O}(0.1 \% \mathrm{HCOOH})$. Gradient: $0 \mathrm{~min}-0 \% \mathrm{~A}, 0.01 \mathrm{~min}-0 \% \mathrm{~A}, 1.5 \mathrm{~min}-$ $100 \%$ A, $1.7 \mathrm{~min}-100 \% \mathrm{~A}, 1.71 \mathrm{~min}-0 \% \mathrm{~A}$. The injection volume $1.0 \mu \mathrm{L}$. The column temperature: $40{ }^{\circ} \mathrm{C}$. DAD: $215,254 \mathrm{~nm}$.

\section{Mass-spectrometry conditions}

Ion Source: API-ES. Scan. Mass Range: m/z 70-600. Fragmentor voltage: 100V. Positive and negative polarity.

\section{Procedure for interaction of acetylcysteine with 2,3-dichloro-1,4-naphthoquinone}

To the solution of $0.66 \mathrm{~g}$ ( $4 \mathrm{mmol}$ ) of acetylcysteine in $10 \mathrm{ml}$ of (DMF) solution of $0.91 \mathrm{~g}$ (mmol) of 2,3-dichloro-1,4-naphthoquinone in $10 \mathrm{ml}$ of DMF was added. The formed mixture was shaken and heated on a water bath within $30 \mathrm{~min}$ at the $95^{\circ} \mathrm{C}$. Then the reaction mixture was cooled and poured into the purified water. For ${ }^{1} \mathrm{H}$ NMR analysis compound $\mathbf{3}$ was recrystallized from 2-propanol. The isolated product of the reaction is yellow-brown crystals soluble in DMF, acetonitrile, 1,4-dioxane, slightly soluble in water, ethanol, 2-propanol. The yield of the obtained chemical compound is $1.0 \mathrm{~g}$.

2,3-dichloro-1,4-napththoquinone (1) IR $\left(\mathrm{cm}^{-1}\right)$ : 1678, 1530, 950, 985; ${ }^{1} \mathrm{H}$ NMR (400 MHz, DMSO-d $\mathrm{d}_{6}$ ), $\delta$ : 8.20-8.01 (m, 2H, naphthalene H-5,8), 7.97-7.76 (m, 2H, naphthalene H-6,7); LC-MS (APCI): $m / z=227$

Acetylcysteine (2) IR $\left(\mathrm{cm}^{-1}\right): 3300,2550,1712,1680,1530,950,985 ;{ }^{1} \mathrm{H}$ NMR (400 MHz, DMSO-d $\left.{ }_{6}\right), \delta: 12.71(\mathrm{~s}, 1 \mathrm{H}, \mathrm{COOH}), 8.16(\mathrm{~d}, 1 \mathrm{H}, \mathrm{NH}) 4.37(\mathrm{td}, 1 \mathrm{H}, \mathrm{CH}) 2.90-2.79\left(\mathrm{~m}, 1 \mathrm{H}, \mathrm{CH}_{2}\right), 2.76-$ $2.62\left(\mathrm{~m}, 1 \mathrm{H}, \mathrm{CH}_{2}\right), 2.41(\mathrm{bs}, 1 \mathrm{H}, \mathrm{SH}), 1.87\left(\mathrm{~s}, 3 \mathrm{H}, \mathrm{CH}_{3}\right)$; LC-MS (APCI): $m / z=164$.

$\mathrm{N}$-acetyl-S-(3-chloro-1,4-dioxo-1,4-dihydronaphthalen-2-yl)cysteine (3). IR ( $\left.\mathrm{cm}^{-1}\right)$ : 1679, 1662, 1557, 910, 1273, 1137, 820, 705, 639; ${ }^{1} \mathrm{H}$ NMR (400 MHz, DMSO-d 6 ), $\delta: 8.34$ (d, 1H, NH), 8.06-7.97 (m, 2H, naphthalene H-5,8), 7.88-7.85 (m, 2H, naphthalene H-6,7), 4.57-4.45 (m, 1H, CH), 3.91-3.75 $\left(\mathrm{m}, 1 \mathrm{H}, \mathrm{CH}_{2}\right), 3.55-3.43\left(\mathrm{~m}, 1 \mathrm{H}, \mathrm{CH}_{2}\right), 1.69\left(\mathrm{~s}, 3 \mathrm{H}, \mathrm{CH}_{3}\right)$; LC-MS (APCI): $m / z=354$

\section{Procedure for interaction of taurine with sodium 1,2-naphthoquinone-4-sulfonate}

To the solution of $3.1 \mathrm{~g}$ of taurine $(25 \mathrm{mmol})$ in $50 \mathrm{ml}$ of purified water solution of $6.5 \mathrm{~g} \mathrm{(25}$ mmol) of sodium 1,2-naphthoquinone-4-sulfonate in $50 \mathrm{ml}$ of purified water was added. A mixture was shaken, then $1.0 \mathrm{~g}$ of crystalline $\mathrm{NaOH}$ was added. The reaction mixture was heated on a water bath 
during $5 \mathrm{~min}$ at $95^{\circ} \mathrm{C}$. The obtained mixture was cooled. The solvent was removed under vacuum using rotary evaporator. Yield of the obtained compound is $8.0 \mathrm{~g}(75.47 \%)$.

\section{Procedure for interaction of $\beta$-alanine with sodium 1,2-naphthoquinone-4-sulfonate}

To the solution of $2.23 \mathrm{~g}$ of $\beta$-alanine $(25 \mathrm{mmol}$ ) in $50 \mathrm{ml}$ of purified water solution of $6.5 \mathrm{~g} \mathrm{(25}$ mmol) of sodium 1,2-naphthoquinone-4-sulfonate in $50 \mathrm{ml}$ of purified water was added. A mixture was shaken, then $1.0 \mathrm{~g}$ of crystalline $\mathrm{NaOH}$ was added. The reaction mixture was heated on a water bath during $10 \mathrm{~min}$ at $60^{\circ} \mathrm{C}$. The obtained mixture was cooled. The solvent was removed under vacuum using rotary evaporator. The yield of the obtained product is $8.6 \mathrm{~g}$.

LC-MS (APCI): compound 7: $\mathrm{tR}=0.834 \mathrm{~min}, \mathrm{~m} / z=282$; compound 8: $\mathrm{tR}=0.766 \mathrm{~min}, \mathrm{~m} / z=$ 246; compound 9: $\mathrm{tR}=1.077 \mathrm{~min}, \mathrm{~m} / z=389$; compound 10: $\mathrm{tR}=0.991 \mathrm{~min}, \mathrm{~m} / z=317$; compound 11: $\mathrm{tR}=0.678 \mathrm{~min}, \mathrm{~m} / \mathrm{z}=563$; compound $12: \mathrm{tR}=0.871 \mathrm{~min}, \mathrm{~m} / \mathrm{z}=491$.

\section{RESULT AND DISCUSSION}

\section{Determination of stoichiometric coefficients of reactants in reactions}

In order to determine the stoichiometric coefficients of reactants in reactions between the selected pharmaceutical substances and some naphthoquinone derivatives, the most common methods were used: method of continuous changes (method of isomolar series) and saturation method (method of molar ratios). Method of continuous changes is based on the determination of relations of isomolar concentrations of reacting substances, which corresponds to the maximum yield of the product formed. We cite the principle of determination of stoichiometric coefficients between taurine and sodium 1,2naphthquinone-4-sulfonate as an example. For carrying out the chemical analysis, solutions of the reagent and the pharmaceutical substance under study of the same molar concentration $(0.005 \mathrm{M})$ were prepared and mixed in inverse ratios (from 1:9 to 9:1), leaving the total volume of the solution unchanged. The reaction was carried out in accordance with the methodology developed. Absorption of the solutions formed was measured at the selected analytic wavelength. A diagram of dependence of the absorption on the relation between the volumes of components of isomolar series was constructed based on the data obtained (Figure 1).

Method of molar ratios is a widely used method of study of compounds. The principle of the method is to define the dependence on the concentration of one of the components at the steady-state concentration of another and vice versa. A break point of the curve corresponds to the ratio of stoichiometric coefficients, which is equal to the equivalent concentration of components (Figure 2).

As is clear from figures 1 and 2, stoichiometric ratios of reactants "taurine - sodium 1,2naphthoquinone-4-sulfonate", obtained by the methods of continuous changes and the saturation method, fully correlate with one another as the $1: 1$ ratio. 


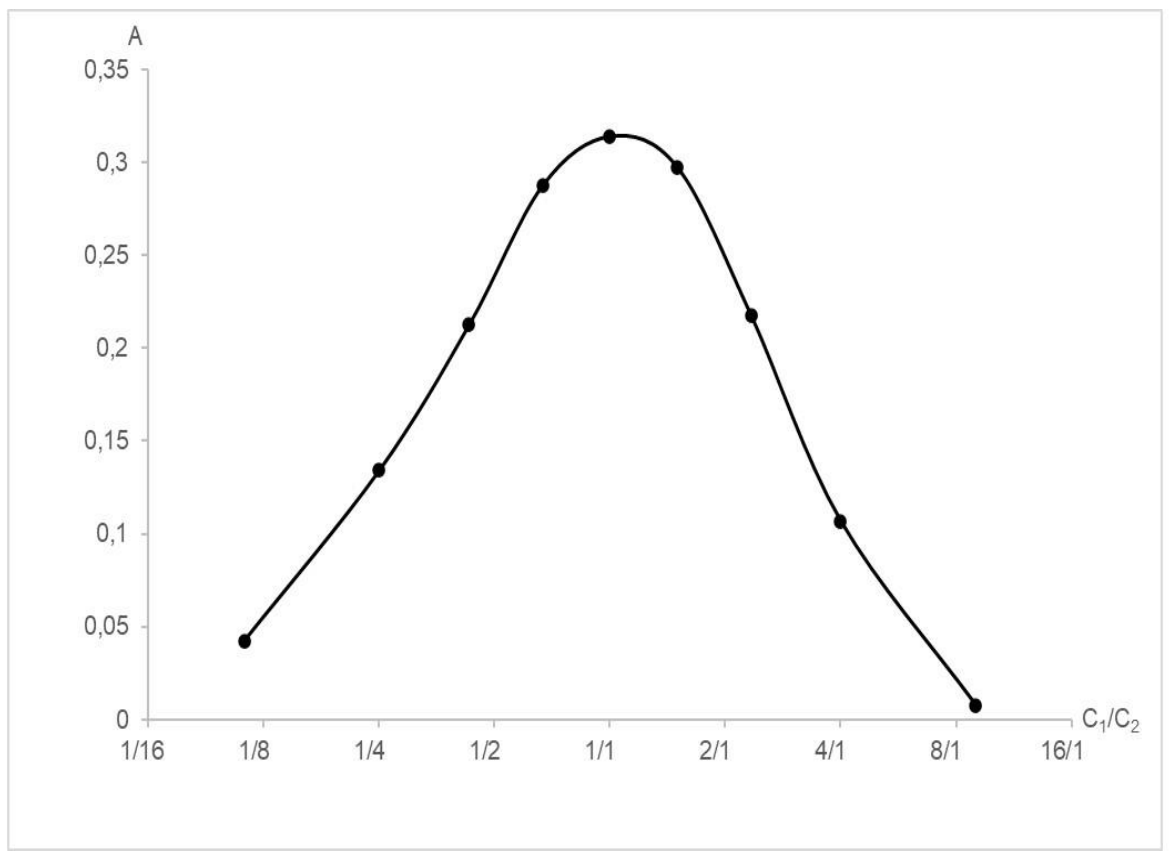

Figure 1. The graph of the absorbance values as a function of isomolar solution composition $\left(\mathrm{C}_{1}\right.$ $-0.005 \mathrm{M}$ NQS solution, $\mathrm{C}_{2}-0.005 \mathrm{M}$ taurine solution)

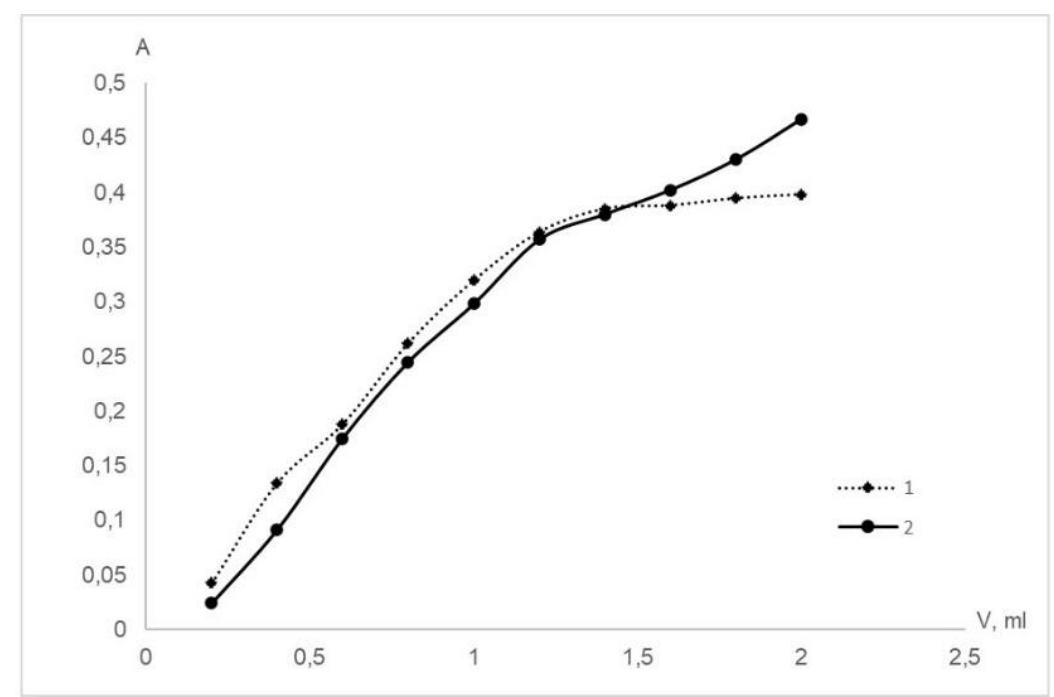

Figure 2. The saturation curves: 1 - sodium 1,2-naphthoquinone-4-sulfonate at constant concentration of taurine ( $1 \mathrm{ml} 0.005 \mathrm{M}$ solution); 2 - taurine at constant concentration of sodium 1,2-naphthoquinone-4-sulfonate ( $1 \mathrm{ml} 0.005 \mathrm{M}$ solution)

Using the results of the above-mentioned methods, we have determined stoichiometric ratios of reactants "pharmaceutical substance - reagent", which clearly correlate with one another (Table 1). 
Table 1. Stoichiometric ratios of reactants «pharmaceutical substance - reagent»

\begin{tabular}{|l|c|c|}
\hline \multirow{2}{*}{ Pharmaceutical substance - reagent } & \multicolumn{2}{|c|}{ Methods } \\
\cline { 2 - 3 } & $\begin{array}{c}\text { Method of isomolar } \\
\text { series }\end{array}$ & Method of molar ratios \\
\hline Acetylcysteine - 2,3-dichloro-1,4-napththoquinone & $1: 1$ & $1: 1$ \\
\hline Taurine - sodium 1,2-naphthoquinone-4-sulfonate & $1: 1$ & $1: 1$ \\
\hline 3-Alanine - sodium 1,2-naphthoquinone-4-sulfonate & $1: 1$ & $1: 1$ \\
\hline
\end{tabular}

Isolation and structural elucidation of products of interaction between the investigative pharmaceutical substances and naphthoquinone derivatives

Colored product of interaction of acetylcysteine with 2,3-dichloro-1,4-naphthoquinone was isolated and identified using LC-MS and ${ }^{1} \mathrm{H}$ NMR methods. LC-MS spectra showed that interaction between abovementioned reagents resulted single product with $\mathrm{m} / \mathrm{z}=227$.

${ }^{1} \mathrm{H}$ NMR-spectroscopy was used for confirmation of the structure of the formed products of the reaction. Comparing of characteristic protons chemical shifts in ${ }^{1} \mathrm{H}$ NMR spectra of acetylcysteine (2), 2,3-dichloro-1,4-naphthoquinone (1) and product (3) as well as LC-MS data analysis allowed to identify a product as $\mathrm{N}$-acetyl-S-(3-chloro-1,4-dioxo-1,4-dihydronaphthalene-2-yl)cysteine. Thus, nucleophilic substitution of halogen in 2,3-dichloro-1,4-naphthoquinone by mercapto-group of acetylcysteine occurred (Figure 3).<smiles>O=C1C(Cl)=C(Cl)C(=O)c2ccccc21</smiles>

1<smiles>CC(=O)NC(CS)C(=O)O</smiles>

2<smiles>CC(=O)NC(CSC1=C(Cl)C(=O)c2ccccc2C1=O)C(=O)O</smiles>

3

Figure 3. Reaction of acetylcysteine with 2,3-dichloro-1,4-naphthoquinone

The following spectral characteristics confirm the structure of the above-mentioned compound 3: the disappearance of a characteristic signal of - SH-group proton (2.41 ppm) in the spectrum; a slight paramagnetic shift (by $0.2 \mathrm{ppm}$ ) and a change of multiplicity (from triplet doublet to multiplet) of a classifying signal of a proton of the asymmetrical - $\mathrm{CH}$-group. A singlet of the $\mathrm{NH}$-group also has a paramagnetic shift (by $0.18 \mathrm{ppm}$ ), one-proton multiplet signals of the $-\mathrm{CH}_{2}$-group at the chiral center by 0.9-0.8 ppm, and a triple-proton singlet of a methyl group of an acyl residue - by 0.2. ppm. Adding acetylcysteine residue to 2,3-dichloro-1,4-naphthoquinone, as expected, causes a diamagnetic shift of aromatic protons of positions $5,6,7$ and 8 by $0.14 \mathrm{ppm}$. 
IR-spectra of the reaction product $\mathbf{3}$ additionally proved the structure of obtained compounds. Comparing of IR-spectra of the reaction product (3) with the spectra of acetylcysteine (2) and 2,3dichloro-1,4-napththoquinone (1) revealed that main bands of absorption of initial reagents had also been observed in the spectrum of the reaction product (3). However, as expected, stretching vibrations of the NH- and SH-groups in the spectrum of the compound 3 disappear at $3300 \mathrm{~cm}^{-1}$ and $2550 \mathrm{~cm}^{-1}$, respectively. There must be a certain bathochromic shift (by $20-30 \mathrm{~cm}^{-1}$ ) of, stretching vibrations of the CO-group of carboxylic acids (resonates together with $v_{\mathrm{C}=\mathrm{O}}$ dichlone at $1679 \mathrm{~cm}^{-1}$ ) and $v_{\mathrm{CO}}$-("Amide I"). Moreover, adding a substituent with donor properties to a molecule leads to a significant reduction of the strength of stretching vibrations $-\mathrm{C}=\mathrm{C}$-bond in the aromatic system. The above-mentioned facts clearly substantiate the reaction of nucleophilic substitution between acetylcysteine and 2,3-dichloro-1,4naphthoquinone and the formation of a new reaction product.

Further, the interactions of sodium 1,2-naphthoquinone-4-sulfonate(4) with taurine (5) and alanine (6) were studied (Figure 4). LC-MS-spectra revealed that both reactions resulted mixtures that consist of two major and traces of one minor products. Considering $\mathrm{m} / \mathrm{z}$ values and literature data [18] one of the major components were identified as products of sulfo-group substitution (compound $\mathbf{7}$ or 8 with $m / z=282$ and $m / z=246$ correspondingly). The second major products of the reaction had the doubled relative to the compounds 7 or 8 value of $m / z$ and probably were the dimers of abovementioned compounds. In view of the nature and position of reaction centers in molecules of compounds $\mathbf{7}$ and $\mathbf{8}$, it was proposed that their dimers were formed as result of addition of nucleophilic amino-group to the double bond of oxo-fragment (compounds 11 and 12 with $\mathrm{m} / \mathrm{z}$ values 563 and 491 respectively). We emphasize that formation of the products like compounds $\mathbf{1 1}$ and $\mathbf{1 2}$ were not previously reported. The minor products had $\mathrm{m} / \mathrm{z}$ values that allowed to identify them as products of nucleophilic addition followed by elimination reaction of compounds $\mathbf{7 , 8}$ and corresponding analytes (compounds $\mathbf{9}$ and $\mathbf{1 0}$ ). It should be noted that nature and content of the products completely agreed with evaluated stoichiometric ratios.

Summing up the above, we studied the interaction between naphthoquinone colorizing reagents and such analytes as acetylcysteine, taurine, and $\beta$-alanine. We evaluated the structure of the products of the reaction and showed that their nature corresponded to the found stoichiometric ratios. Also, we revealed the previously unknown process of products dimerization when quantifying taurine and $\beta$ alanine using sodium 1,2-naphthoquinone-4-sulfonate as colorizing reagent.

Conducted studies revealed that reaction of acetylcysteine with 2,3-dichloro-1,4naphthoquinone proceeded unambiguously and yielded one product namely N-acetyl-S-(3-chloro-1,4dioxo-1,4-dihydronaphthalen-2-yl)cysteine. The reaction between sodium 1,2-naphthoquinone-4sulfonate and $\beta$-alanine (or taurine) resulted the mixture wherein product of substitution of sulfonic group by amine moiety and its dimer were identified as main component. The structures of products 
were proposed according to the $\mathrm{m} / \mathrm{z}$ values and nature of reactional centers in interacting molecules. The obtained information is valuable for future development of spectrophotometric methods based on the usage of naphthoquinone colorizing agents.<smiles>O=C1C=Cc2ccccc2C1=O</smiles><smiles></smiles>

4<smiles>[X]CCNC1=CC(=O)C(=O)c2ccccc21</smiles>

7,8

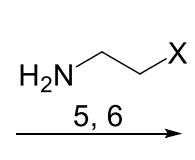<smiles>O=C1C=Cc2ccccc2C1=O</smiles><smiles>[X]CCN</smiles>

7,8<smiles>[X]CCN</smiles>

$\mathrm{O}$<smiles>[X]CCN=C1C(=O)C=Cc2ccccc21</smiles><smiles>[X]CCN</smiles>

9,10<smiles></smiles>

11,12

$5,7,9,11 X=\mathrm{SO}_{3} \mathrm{H} ; 6,8,10,12 \mathrm{X}=\mathrm{COOH}$

Figure 4. Reaction of sodium 1,2-naphthoquinone-4-sulfonate with taurine and $\beta$-alanine.

\section{AUTHOR CONTRIBUTIONS}

Conception: A.D., K.M., O.V.; Design: S.V., S.K.; Supervision: A.D., K.M., O.V., S.V., S.K.; Resources: S.V., S.K.; Materials: S.V., S.K.; Data collection and/or processing: A.D., K.M., O.V.; Analysis and/or interpretation: A.D., K.M., O.V.; Literature search: O.V; Writing manuscript: A.D., K.M., O.V., S.V., S.K.; Critical review: A.D., K.M., O.V., S.V., S.K.; Other: -

\section{CONFLICT OF INTEREST}

The authors declare no conflict of interest.

\section{REFERENCES}

1. Pinto, A.V., Lisboa de Castro, S. (2009). The trypanocidal activity of naphthoquinones: a review. Molecules, 14(11), 4570-4590. doi:10.3390/molecules14114570

2. Tandon, V.K., Kumar, S. (2013). Recent development on naphthoquinone derivatives and their therapeutic applications as anticancer agents. Expert Opinion on Therapeutic Patents, 23(9), 1087-1108. doi:10.1517/13543776.2013.798303 
3. Reuillard, B., Le Goff, A., Agne`s, C., Holzinger, M., Zebda, A., Gondran, C., Elouarzaki, K., Cosnier, S. (2013). High power enzymatic biofuel cell based on naphthoquinone-mediated oxidation of glucose by glucose oxidase in a carbon nanotube 3D matrix. Physical Chemistry Chemical Physics, 15, 4892-4896. doi: 10.1039/c3cp50767j

4. Ibis, C., Deniz, N.G. (2010). Synthesis and spectroscopic properties of S-,O-Substituted naphthoquinone dyes . Phosphorus, sulfur, silicon and the related elements, 185(11), 23242332. doi:10.1080/10426501003598671

5. Abou-Ouf, A., Taha, A.M., Saidhom, M. (1973). Spectrophotometric analysis of primary aliphatic amines with dichlone. Journal of Pharmaceutical Sciences, 62(10), 1700-1702. doi:10.1002/jps.2600621028

6. Shishoo, C.J., Suhagia, B.N., Rathod, I.S., Thakore, S.S. (1996). Spectrophotometric estimation of piperazine in dosage forms using Dichlone and Acetaldehyde as reagents. Indian Journal of Pharmaceutical Sciences, 58(6), 219-221.

7. Alzoman, N.Z., Alshehri, J.M., Darwish, I.A., Khalil, N.Y., Abdel-Rahman, H.M. (2015). Charge-transfer reaction of 2,3-dichloro-1,4-naphthoquinone with crizotinib: Spectrophotometric study, computational molecular modeling and use in development of microwell assay for crizotinib. Saudi Pharmaceutical Journal, 23, 75-84. doi:10.1016/j.jsps.2014.06.003

8. Devani, M.B., Shishoo, C.J., Patel, M.A., Bhalara, D.D. (1978). Spectrophotometric Determination of Isoniazid in Presence of Its Hydrazones. Journal of Pharmaceutical Sciences, 67(5), 661-663. doi:10.1002/jps.2600670523

9. Elbashir, A.A., Ahmed, A.A., Ahmed, S.M.A., Aboul-Enein, H.Y. (2012). 1,2Naphthoquinone-4-sulphonic acid sodium salt (NQS) as an analytical reagent for the determination of pharmaceutical amine by spectrophotometry. Applied Spectroscopy Reviews, 47(3), 219-232. http://dx.doi.org/10.1080/05704928.2011.639107

10. Fan, B., Geng, M., Wang, Y., Lia, Q. (2013). Spectrophotometric Determination of Cefotaxime by Using Sodium 1,2-Naphthoquinone-4-Sulfonate. Journal of Analytical Chemistry, 68(11), 965-968. doi: 10.1134/S1061934813110038

11. Ahmed, S.M.A., Elbashir, A.A., Aboul-Enein, H.Y. (2015). New spectrophotometric method for determination of cephalosporins in pharmaceutical formulations. Arabian Journal of Chemistry, 8(2), 233-239. doi:10.1016/j.arabjc.2011.08.012

12. Ahmed, S.M., Elbashir, A. A. (2015). Development and validation of spectrophotometric method for determination of finasteride in pharmaceutical formulation using 1,2-Naphthoquine4-sulfonate (NQS). Journal of Analytical \& Bioanalytical Techniques, 6(3), 1000248. doi:10.4172/2155-9872.1000248

13. Al-Araji, R.R., Mashkour, M.S., Al-Mulla, E.A.J. (2017). Spectrophotometric Determination of Vitamin Folic Acid B9 in Some Drugs Using 2-Naphthoquine-4-Sulphonate (NQS). Nano Biomedicine and Engineering, 9(3), 208-213. doi: 10.5101/nbe.v9i3.p208-213

14. Muszalska, I., Sobczak, A., Kiaszewicz, I., Rabiega, K., Lesniewska, M.A., Jelinska, A., (2015). 1,2-Naphthoquinone-4-sulfonic acid sodium salt as a reagent for spectrophotometric 
determination of rimantadine and memantine. Journal of Analytical Chemistry, 70(3), 320-327. doi:10.1134/s106193481503012015

15. Saurina, J., Hernández-Cassuo, S. (1993). Continuous-flow spectrophotometric determination of amino acids with 1,2-naphthoquinone-4-sulphonate reagent. Analytica Chimica Acta, 283(1), 414-420. doi:10.1016/0003-2670(93)85252-f

16. Li, Q., Li, J., Yang, Z. (2007). Study of the sensitization of tetradecyl benzyl dimethyl ammonium chloride for spectrophotometric determination of dopamine hydrochloride using sodium 1,2-naphthoquinone-4-sulfonate as the chemical derivative chromogenic reagent. Analytica Chimica Acta, 583, 147-152. doi: 10.1016/j.aca.2006.09.051

17. Nagaraja, P., Srinivasa, Murthy, K.C., Yathirajan, H.S. (1996). Spectrophotometric determination of isoniazid with sodium 1,2-naphthoquinone-4-sulphonate and cetyltrimethyl ammonium bromide. Talanta, 43, 1075-1080. doi: 10.1016/0039-9140(95)01864-6

18. Asahi, Y., Tanaka, M., Shinozaki, K. (1984). Reaction of 1,2-naphthoquinone-4-sulfonate with aliphatic amines: Structure of the colored products and kinetics. Chemical and Pharmaceutical Bulletin, 32(8), 3093-3099. doi: 10.1248/cpb.32.3093

19. Delarmelina, M., Greco, S.J., Carneiro, J.W. (2017). Single step mechanism for nucleophilic substitution of 2,3-dichloro naphthoquinone using nitrogen, oxygen and sulfur nucleophiles: A DFT approach. Tetrahedron, 73(30), 4363-4370. doi:10.1016/j.tet.2017.05.095

20. Miedviedieva, K.P., Donchenko, A.O., Vasiuk, S.O. (2019). Application of quinone derivatives for spectrophotometric determination of drugs. Current Issues in Pharmacy and Medicine: Science and Practice, 3(31), 250-255. doi:10.14739/2409-2932.2019.3.184173

21. Portnaya, E.P., Vasyuk, S.A. (2014). Spectrophotometric determination of taurine in dosage forms using sodium 1,2-naphthoquinone-4-sulfonate. Pharmaceutical Chemistry Journal, 48(8), 553-557. doi: 10.1007/s11094-014-1150-3 